DOI: $10.18276 / \operatorname{sip} .2017 .47 / 1-06$

\title{
Malgorzata Zakrzewska*
}

Uniwersytet Szczeciński

\section{CASE STUDY JAKO AKCELERATOR TRANSMISJI WIEDZY I ROZWOJU GOSPODAREK OPARTYCH NA WIEDZY}

\begin{abstract}
STRESZCZENIE
Znaczenie kształcenia ekonomicznego i tego z zakresu przedsiębiorczości we współczesnej gospodarce opartej na wiedzy jest niepodważalne, ważna jest jednak nie tylko nauczana treść, ale również stosowane metody nauczania. Case study może być dobrym narzędziem nauczania w edukacji ekonomii i przedsiębiorczości, ponieważ jest zorientowane na problem, a także na studenta, oraz uwzględnia pracę zespołową. Wykorzystanie metody case study ułatwia analizę postaw przedsiębiorczych i praktyki gospodarczej. Case study, poprzez kształtowanie kompetencji miękkich, pobudza transmisję wiedzy, ułatwia jej absorbcję, dzięki czemu może przyczyniać się do rozwoju gospodarek opartych na wiedzy.
\end{abstract}

Słowa kluczowe: case study, wiedza, gospodarka oparta na wiedzy

\section{Wprowadzenie}

Celem niniejszego artykułu jest ukazanie zastosowania metody case study w procesie transmisji wiedzy i znaczenia, jakie może ona mieć w procesie edukacji przedsiębiorczej i rozwoju gospodarek opartych na wiedzy. Znaczenie wiedzy dla

\footnotetext{
*Adres e-mail: malgorzata.zakrzewska@usz.edu.pl.
} 
tworzenia i rozwoju gospodarek jest niepodważalne. Związane jest to także ze zmianą modeli współczesnych gospodarek i społeczeństw - z industrialnych na postindustrialne, w których dominującą rolę pełni sektor usług wzmocniony o badania, istnienie organizacji i przede wszystkim innowacje, które uzależnione są z jednej strony od zasobów wiedzy, z drugiej zaś od umiejętności transmisji wiedzy w danej gospodarce.

Wiedza może być zdobywana przez edukację dwojakiego rodzaju: formalną i nieformalną. Edukacja formalna odbywa się na poziomie kształcenia szkolnego, oparta jest na ustalonych zasadach i programach. Z kolei edukacja nieformalna to taka, która odbywa się na zewnątrz edukacji formalnej, tzn. nie jest oparta na określonych zasadach. Charakterystyczna dla niej jest dobrowolność uczestniczenia, proces nauczania odbywa się na wielu płaszczyznach. W obu tych przypadkach, aby mógł zajść proces edukacji, należy stworzyć korzystne warunki do transmisji wiedzy, czyli do przyswojenia jej przez jej odbiorców. Aby wiedza mogła być zaabsorbowana, musi pochodzić nie tylko z wiarygodnego źródła, ale również mieć odpowiednią formę i być użyteczna na etapie jej wykorzystywania (Penc, 2011, s. 20). Istotna jednak jest nie tylko zawartość merytoryczna wiedzy, edukacji ekonomicznej i przedsiębiorczej, ale też wykorzystywane metody dydaktyczne (Gaweł, 2012), dlatego metoda case study może stanowić wartościowe narzędzie w edukacji przedsiębiorczej.

\section{Wiedza i edukacja w gospodarce opartej na wiedzy}

Wiedza jest podstawą działania i rozwoju jednostek, społeczeństw, przedsiębiorstw i podstawą zdobywania oraz utrzymywania przez nie przewagi konkurencyjnej we współczesnej gospodarce opartej na wiedzy. Wygrywają te podmioty, które są zdolne do tworzenia wiedzy szybciej niż ich konkurenci (Maskell, Malmberg, 1999). Wiedza traktowana jest również jako kluczowy czynnik budujący konkurencyjność gospodarek (Huggins, 2008), jej transmisja niezbędna jest do rozwoju gospodarek opartych na wiedzy (GOW). Celem zasadniczym GOW jest efektywne wykorzystanie i gromadzenie wiedzy, a tym samym spowodowanie przewagi konkurencyjnej gospodarek i przedsiębiorstw. Wiedza jest natomiast „,tworzona, zdobywana, transmitowana oraz używana” (Skrzypek, Grela, 2006, s. 87) przez podmioty gospodarcze oraz jednostki i wspólnoty występujące w społeczeństwie. Aby można 
było mówić o stałym rozwoju GOW, muszą zadziałać: efekt synergii oraz współpraca w społeczeństwie (Zakrzewska, 2014). Ich poziom zależy od poziomu zaufania, komunikacji, partycypacji społecznej oraz aktywności obywatelskiej, czyli od tzw. kompetencji społecznych, czy też kompetencji miękkich. Te zaś są częściami składowymi kapitału społecznego oraz gospodarki opartej na wiedzy, co podkreśla istotę rozwoju tychże kompetencji, np. poprzez wykorzystywanie case study w procesie transmisji wiedzy.

Szkolnictwo wyższe i studia są jednym z elementów transmisji wiedzy. W szkolnictwie wyższym następuje generowanie nowej wiedzy za pomocą procesów badawczo-naukowych i - jednocześnie - dyfuzja tej wiedzy dzięki procesowi edukacyjnemu. Dodatkowo edukacja formalna w szkolnictwie wyższym pozwala nie tylko na zdobycie nowej wiedzy, ale też na uzyskanie kompetencji i umiejętności oraz kształci postawy (Gaweł, 2012, s. 29). Uważa się, że edukacja uniwersytecka wyrabia postawę proinnowacyjną. Wyższe wykształcenie jest jednym z czynników, które w znaczący sposób wpływają na przedsiębiorczą innowacyjność jednostek (Koellinger, 2008). Osoba z wyższym wykształceniem ma również większą skłonność do inicjowania i wdrażania innowacji. Poziom wykształcenia może mieć również znaczenie w przypadku inicjowania własnej działalności gospodarczej. Podkreśla się, że osoby z wyższym wykształceniem są skłonne do zakładania innowacyjnych, a nie naśladowczych, przedsiębiorstw (Koellinger, 2008), dzięki czemu do gospodarki wdrażane są nowe rozwiązania biznesowe, następuje zatem transmisja wiedzy.

\section{Edukacja ekonomiczna i przedsiębiorcza w gospodarce opartej na wiedzy}

Wzrost poziomu edukacji ekonomicznej i przedsiębiorczości mogą przyczynić się do poprawy produktywności i efektywności (Smith, Beasley, 2011), a co za tym idzie - przyśpieszenia transmisji wiedzy i de facto innowacji. Uważa się, że edukacja ekonomiczna i przedsiębiorcza może być kluczowym czynnikiem w promocji aktywności przedsiębiorczej (Nabi, Linan, 2011). Będzie to jednak możliwe tylko wtedy, gdy proces nauczania będzie związany z procesem rozumienia rzeczywistości, czyli odwołania się do podejścia ,uczenia się” i obserwacji w procesie transmisji wiedzy. Zrozumienie istoty procesu, czy też rzeczywistości, a nie wyłącznie zapamiętywanie, jest bardziej pomocne w kształtowaniu postaw przedsiębiorczych oraz powoduje rozwój wiedzy ekonomicznej. Podkreśla się, że proces edukacyjny ukie- 
runkowany na zrozumienie rzeczywistości może być efektywny dla przedsiębiorców. Edukacja przedsiębiorcza powinna być zatem wieloaspektowa, dawać nie tylko wiedzę teoretyczną i zrozumienie, ale również kształcić umiejętności przydatne do zakładania, prowadzenia i rozwijania przedsiębiorstwa (Balan, Metcalfe, 2012).

Idąc dalej, efektywność edukacji ekonomicznej i przedsiębiorczej, i de facto - szybkość transmisji wiedzy, zależne będą od właściwej metody użytej do jej realizacji. W literaturze przedmiotu podkreśla się wagę podejścia do nauczania zorientowanego na rozwiązywanie problemu (Tan, Ng, 2006). Proces transmisji wiedzy powinien wykorzystywać wszystkie możliwe aspekty edukacyjne: programy nauczania, aktywność studentów poza ścieżką studiów oraz wsparcie ze strony uniwersytetów dla studentów i absolwentów, ułatwiające uruchomienie własnej firmy (Smith, Beasley, 2011). Dodatkowo, kompleksowość procesu kształtowania wiedzy ekonomicznej i rozwoju postaw przedsiębiorczych powoduje, że proces ten wymaga szczególnego zaangażowania studentów (Balan, Metcalfe, 2012). Im bardziej angażujący jest proces dydaktyczny, tym większy jest poziom przyswojenia nowych umiejętności przedsiębiorczych przez studentów (Gaweł, 2012).

\section{Case study w edukacji ekonomicznej i przedsiębiorczej}

Pytanie o skuteczność edukacji przedsiębiorczej jest ściśle związane z kwestią stosowanych metod dydaktycznych. Wykorzystanie odpowiednich metod nauczania może stanowić klucz do sukcesu edukacji przedsiębiorczej. Jedynie głębokie podejście może dać wymierne korzyści w edukacji przedsiębiorczej. Jedną z metod nauczania, wymuszającą głębokie podejście, jest metoda case study. Metoda ta może być używana zarówno w celach naukowych, jak i dydaktycznych. Jako metoda dydaktyczna zakłada opisanie specyficznej sytuacji biznesowej i zachęcenie studentów do analizowania oraz spójnej oceny tej sytuacji (Little i in., 2008). Analiza ta koncentruje się na czynnikach, które wpływają na relacje między badaną gospodarką a jej otoczeniem, jak również na określeniu, w jaki sposób jeden szczególny przypadek jest odzwierciedleniem bardziej ogólnych zjawisk (Flyvbjerg, 2011).

Pracując z metodą studium przypadku (case study), studenci poznają określoną sytuację, dzięki czemu ich nauczanie jest bliższe praktyce (Gaweł, 2012, s. 32). W metodzie studium przypadku przedstawia się specyficzny problem lub wydarzenie bazujące na prawdziwych sytuacjach biznesowych. Studium przypadku z reguły 
przedstawia wydarzenie, ludzi zaangażowanych w nie oraz okoliczności, które miały wpływ na to wydarzenie (Roselle, 1996). Wykorzystanie tej metody w procesie nauczania wymusza użycie danych ilościowych i jakościowych, podejmowanie decyzji na podstawie najbardziej właściwych działań i rekomendacji oraz dyskutowanie tych decyzji z innymi uczącymi się (Cranston, 2008). Studenci są postawieni na miejscu osób biorących udział w opisywanej sytuacji i mają za zadanie przeanalizować z różnych punktów widzenia oraz wskazać decyzje, które ich zdaniem byłyby najkorzystniejsze.

Uważa się, że metoda studium przypadku ma następujące właściwości (Jaques, 2008): daje możliwość przeanalizowania funkcjonowania organizacji biznesowej, zachęca do myślenia o potencjalnych rozwiązaniach, wskazuje na przykłady właściwych i niewłaściwych, użytecznych i nieużytecznych zachowań biznesowych, zachęca do dyskusji o alternatywnych opcjach rozwiązań, stwarza możliwość zastosowania wiedzy teoretycznej w praktycznych sytuacjach biznesowych. Case study zorientowane jest na studenta, ponieważ zachęca studentów do przemyśleń na temat tego, czego się dotychczas uczyli (Gregory, Jones, 2009). Nauczanie przy wykorzystaniu tej metody ma wymiar w większej mierze praktyczny, a nie teoretyczny, ponieważ bazuje na realnym problemie biznesowym. Case study zorientowane są na pracę zespołową, ponieważ studenci współpracują w małych grupach, by rozwiązać problem (Prince, 2004), a następnie dzielą się swoimi przemyśleniami i wnioskami z innymi, co dowodzi transmisji wiedzy i procesu dydaktycznego. Podczas dyskusji następuje wymiana wiedzy i spostrzeżeń, co rozwija proces uczenia się. Metoda case study jest zorientowana na pracę zespołową i tworzy interakcje w grupie (Gaweł, 2012 ). Dzięki temu zachęca ona studentów do szukania lepszych pomysłów i konkluzji, wyższej jakości strategii, korzyści z interakcji między grupami (Peterson, Quarstein, 2001). Za najistotniejszy wkład case study w procesie dydaktycznym w porównaniu z innymi metodami uważa się to, że kształci ono autonomiczne, bardziej przedsiębiorcze osoby chcące uczyć się przez całe życie, podczas gdy metody bardziej pasywne, ukierunkowane na przedmiot nauczania, kształcą osoby zdobywające wiedzę (Ó Cinneide, 2006). Metoda case study bazuje na sytuacjach przedsiębiorstw, które miały miejsce w rzeczywistości, przez to umożliwia studentom uczenie się w pragmatyczny sposób. Pozwala na wprowadzenie doświadczeń prawdziwego życia do sali lekcyjnej (Ó Cinneide, 2006). Wykorzystanie case study, dzięki rozwiązywaniu problemów i dyskusji o możliwych do zastosowania strategiach, 
może zwiększyć kreatywność studentów (Heinonen, Poikkijoki, 2006). Metoda ta może mieć również zastosowanie $\mathrm{w}$ nauczaniu przedsiębiorczości również $\mathrm{z}$ tego powodu, że odpowiada podejściom opartym na rozwiązywaniu problemów i absorbcji wiedzy poprzez „uczenie się” (Tan, Ng, 2006).

Mimo że metoda case study ma szereg zalet, jej stosowanie obarczone jest kilkoma barierami, które można podzielić na te leżące po stronie dydaktyków oraz studentów.

Bariery wprowadzania metody studium przypadku leżące po stronie dydaktyków można podzielić na powstające podczas przygotowania zajęć i prowadzenia zajęć z wykorzystaniem case study (Gaweł, 2012, s. 39). Najczęściej spotykaną trudnością jest wybór właściwego studium przypadku i opracowanie scenariusza zajęć. Aby case study mógł w ogóle powstać, konieczna jest współpraca z przedsiębiorstwem, którego sytuacja ma być przedmiotem analizy. Jednakże współpraca między biznesem a uczelniami napotyka często problemy. Najistotniejszym zatem krokiem niezbędnym do rozpoczęcia prac nad przygotowaniem metody stanowiącej przedmiot analizy niniejszego artykułu jest podjęcie współpracy między przedstawicielami biznesu i uczelni. $Z$ racji tego, że case study jest metodą wymagającą aktywności i zaangażowania studentów, przed dydaktykiem stoi również konieczność moderowania dyskusji studentów tak, aby zrealizować cele dydaktyczne.

Zastosowanie metody studium przypadku może napotykać również ograniczenia leżące po stronie studentów. Zwykle studenci kierunków ekonomicznych i związanych z przedsiębiorczością zainteresowani są głównie rozwijaniem kompetencji biznesowych, które mogłyby wykształcić wśród nich umiejętności negocjacyjne i przywódcze (Gawel, 2012, s. 32). Case study z istoty swojego charakteru analizuje konkretną sytuację biznesową i decyzyjną przedsiębiorstwa. Pożądany przez studentów rozwój umiejętności negocjacyjnych i przywódczych możliwy jest wówczas, gdy do zajęć wprowadzi się dodatkowe elementy dyskusji w grupach, odgrywanie ról poszczególnych osób z przedsiębiorstwa czy też całego procesu negocjacyjnego. Oznacza to, że studenci zamierzający rozwijać swoje kompetencje negocjacyjne i przywódcze mogą nie być zainteresowani uczestnictwem w zajęciach z wykorzystaniem tej metody, gdyż będą ją postrzegać jako mało użyteczną (Gaweł, 2012, s. 40). 


\section{Podsumowanie}

Na podstawie przedstawionej w niniejszym artykule analizy można stwierdzić, że metoda case study może być cennym i innowacyjnym narzędziem w edukacji ekonomicznej i przedsiębiorczej, głównie ze względu na to, że jej zastosowanie zwiększa efektywność procesu edukacji, ponieważ w znacznym stopniu angażuje uczestników, opiera się na praktyce, czyniąc edukację formalną bardziej zbliżoną do zdobywania wiedzy poprzez „uczenie się”.

Mimo że stosowanie case study wymaga zwiększonych nakładów pracy zarówno ze strony dydaktyków w procesie przygotowania scenariuszy, jak i studentów podczas ich analizy, dzięki zastosowaniu metody case study kształtowane są postawy przedsiębiorcze. Co więcej, prowokowanie pracy zespołowej, stworzenie platformy wymiany poglądów może rozwinąć wysoki poziom zaufania, komunikacji, partycypacji oraz aktywności, czyli tych kompetencji miękkich, które umożliwiają transmisję wiedzy i tym samym mogą pozytywnie wpłynąć na rozwój gospodarek opartych na wiedzy.

\section{Literatura}

Balan, P., Metcalfe, M. (2012). Identifying teaching methods that engage entrepreneurship students. Education and Training, 54, 368-384.

Cranston, N. (2008). The use of cases in the leadership development of principals. A recent initiative in one large education system in Australia. Journal of Educational Administration, 46, 581-597.

Flyvbjerg, B. (2011). Case study. W: N. Denzin, Y. Lincoln (red.), The Sage Handbook of Qualitative Research (s. 301-316). Thousand Oaks, CA: SAGE.

Gaweł, A. (2012). Metoda studium przypadku w edukacji przedsiębiorczej i menedżerskiej w gospodarce opartej na wiedzy. W: P. Ammerman, A. Gawel, M. Pietrzykowski, R. Rauktiene, T. Williamson (red.), Metoda studium przypadku w edukacji biznesowej (s. 27-41). Poznań: Bogucki Wydawnictwo Naukowe.

Gregory, J., Jones, R. (2009). Maintaining competence: a grounded theory typology of approaches to teaching in higher education. Higher Education, 57, 769-785.

Heinonen, J. (2007). An entrepreneurial-directed approach to teaching corporate entrepreneurship at university level. Education and Training, 49, 310-324.

Heinonen, J., Poikkijoki, S. (2006). An entrepreneurial-directed approach to entrepreneurship education: mission impossible? Journal of Management Development, 25, 80-94. 
Huggins, R. (2008). Universities and knowledge-based venturing: finance, management and networks in London. Entrepreneurship and Regional Development, 20, 185-206.

Jaques, T. (2008). A case study approach to issue and crisis management. Schadenfreude or an opportunity to learn? Journal of Communication Management, 12, 192-203.

Koellinger, P. (2008). Why are some entrepreneurs more innovative than others? Small Business Economics, 31, 21-37.

Little, V., Brookes, R., Palmer, R. (2008). Research-informed teaching and teaching-informed research; the Contemporary Marketing Practices (CMP) living case study approach to understanding marketing practice. Journal of Business and Industrial Marketing, 23, 124-134.

Maskell, P., Malmberg, A. (1999). Localised learning and industrial competitiveness. Cambridge Journal of Economics, 23, 167-185.

Nabi, G. Linan, F. (2011). Graduate entrepreneurship in the developing world: intentions, education and development. Education and Training, 53, 325-334.

Ó Cinneide, B. (2006). Developing and teaching student oriented case studies. The production process and classroom/examination experiences with "entertaining" topics. Journal of European Industrial Training, 30, 349-364.

Penc, J. (2011). Zachowania organizacyjne w przedsiębiorstwie. Kreowanie twórczego nastawienia i aspiracji. Warszawa: Wolters Kluwer.

Peterson, P., Quarstein, A. (2001). Assessment of case study courses. Quality Assurance in Education, 9, 46-53.

Prince, M. (2004). Does Active learning Work? A Review of the Research. Journal of Engineering Education, 93 (3), 223-231.

Roselle, A. (1996). The case study method. A learning tool for practicing librarians and information specialists. Library Review, 45, 30-38.

Skrzypek, E., Grela, E. (2006). Knowledge-Based. Economy Determinans - A Comparative Analysis of the Economics of Poland and Other EU Countries. MIC'06 Management International Conference: Advancing Business and Management in Knowledge Based Society, 7th International Conference of the Faculty of Management, Koper, University of Primorska, Slovenia.

Smith, K., Beasley, M. (2011). Graduate entrepreneurs: intentions, barriers and solutions. Education and Training, 53, 722-740.

Tan, S., Ng, C. (2006). A problem-based learning approach to entrepreneurship education. Education and Training, 48, 416-428.

Zakrzewska, M. (2014). Analiza wybranych wymiarów kapitału społecznego - wyniki badań. Studia i Prace Wydziału Nauk Ekonomicznych i Zarządzania, 826, 369-385. 


\title{
CASE STUDY AS AN ACCELERATOR OF KNOWLEDGE TRANSMISSION AND OF THE DEVELOPMENT OF THE KNOWLEDGE-BASED ECONOMIES
}

\begin{abstract}
The importance of economic and entrepreneurship education in the modern knowledge economy is indisputable, where increasing importance is being made not only to the content but also to the methods of teaching. Case study can be a good teaching tool in education, economics and entrepreneurship, because it is task oriented, as well as it involves students and incorporates teamwork. The use of case study method facilitates the analysis of economic behavior and business practice. Case study by the development of soft skills stimulates the transmission of knowledge, facilitates its absorption and may thus contribute to the development of knowledge-based economies.
\end{abstract}

Translated by Matgorzata Zakrzewska

Keywords: case study, knowledge, knowledge-based economy

JEL codes: E24, O15 